\title{
ROLE OF CONSENT IN MEDICAL PRACTICE
}

Vijay Arora

1. Associate Professor. Department of Forensic Medicine, R.P.G.M.C. Kangra at Tanda [H.P.]

\section{CORRESPONDING AUTHOR}

Dr. Vijay Arora,

Associate Professor,

Dept. of Forensic Medicine,

Dr.R.P.G.M.C. Kangra at Tanda [H.P.]-176001

E-mail: drvjarora@gmail.com,

Ph: 00919805739200

ABSTRACT: Consent is a very important issue for all the medical practitioners while dealing with their patients .Consent is always required for examining a patient for therapeutic purpose or while preparing a medico legal report .Ignorance of law is not a defense in legal cases, so all medical practitioners should be aware of their duties with regard to consent in clinical setting. In this article I have discussed various issues in relation to consent, possible word format for taking consent for medico legal examination and the cases where examination can be done without consent.

KEY WORDS: Consent, Implied Consent, Expressed Consent, Informed Consent

INTRODUCTION: CONSENT: The term consent means voluntary agreement, compliance or permission. Section 13 of the Indian contract act says that two or more persons are said to consent when they agree upon the same thing in same sense.

\section{Types of consent:}

Implied Consent

Expressed Consent [May be oral or written]

Implied Consent: Not written, that is, its existence is not expressly asserted, but nonetheless, it is legally effective. It is the most common type of consent in both general and hospital practice. It implies consent to medical examination in a general sense but not to procedures more complex than inspection, palpation and auscultation. Implied consent is apparent when a patient comes to hospital or doctor's clinic for treatment, it is also apparent in a case of comatose patient requiring immediate treatment or a mentally incompetent patient requiring treatment when legal guardian is not available.

Expressed Consent: The terms of which are stated in distinct and explicit language. It may be in oral or written form.

Written should be preferred as it has the advantage of easy proof and permanent form. Oral consent is also equally valid if properly witnessed .Oral consent should be taken in the presence of a disinterested party like any literate paramedical staff e.g. nurse, pharmacist

\section{Informed Consent:}

Doctor should inform the patient regarding: 


\section{DIAGNOSIS:}

Nature of treatment or procedure

Risks involved

Prospects of success

Prognosis if the procedure is not performed

Alternative methods of treatment

Informed consent was practically non-existent till the time COPRA [Consumer protection act] came into existence. This is seen as more of a legal requirement than the ethical moral obligation on part of the doctor towards his patient. ${ }^{2}$

\section{Possible Word Format for Consent for Medico Legal Examination}

A) I $\mathrm{S} / \mathrm{O}, \mathrm{D} / \mathrm{O}, \mathrm{W} / \mathrm{O}$

$\mathrm{R} / \mathrm{O}$

give my full, free voluntary consent for my complete medico legal

examination, the purpose, nature and consequences of which have been

explained to me by $\mathrm{Dr}$.

B) I certify that no other medico legal examination for present injuries has been done earlier anywhere else.

All the particulars told by me to the doctor are correct.

Date: $\quad$ Signature of patient:

C) That all the injuries present on my body have been noted in the medico legal report.

Date: $\quad$ Signature of patient:

(Consent should preferably be in the language of the patient.)

\section{Loco Parentis}

In an emergency involving children, when their parents or guardians are not available, consent is taken from the person in charge of the child e.g. a school teacher can give consent for treating a child who becomes sick during a picnic away from home town, or the consent of the head master of a residential school.

\section{Proxy consent or surrogate decision maker ${ }^{3}$}

When a person is incapable of giving expressed consent a substituted consent can be taken from the next of kin. Generally accepted order is spouse, adult child, parents, siblings, lawful guardians

Consent of relative can also be taken if the consequence of informing the patient about the disease is more dangerous as compared to the actual risk of the procedure.

\section{Consent is invalid if}

The act consented to is unlawful e.g. criminal abortion.

The consent given by a minor or a mentally ill or the one who had no legal capacity to give it.

If it is not an informed consent.

If obtained by misrepresentation or fraud.

Consenting person is under age. 


\section{Informed refusal}

If after knowing about the procedure, its side effects and other information related to procedure patient declines or refuses to undergo the procedure, it must be taken in written. Treatment can not be forced upon any individual who does not want to receive it, except in a very few circumstances like issues associated with public health, military personnel or prisoners.

\section{Consent is must}

In all cases of medical examination and treatment, while preparing Medico legal reports and while examining the victim of a criminal case like rape etc.

\section{Examination without Consent}

Upto1972, there was no provision in the Criminal procedure code under which court can compel the accused person to get himself medically examined. Consequently police faced lots of hardship in investigations especially dealing with criminal cases. Law commission in its $41^{\text {st }}$ report recommended that provision be made in the code of criminal procedures for making lawful the medical examination of the accused at the request of the police. Eventually, bearing all these aspects in mind the parliament included a new provision in the code of criminal procedure 1973 in section 53.

Under Sec 53[1] Cr.P.C.5, when a person is arrested on a charge of committing an offence of such a nature and alleged to have been committed under such circumstances that there are reasonable grounds for believing that an examination of his person will afford evidence as to the commission of an offence, it shall be lawful for a registered medical practitioner, acting at the request of a police officer not below the rank of sub-inspector , and for any person acting in good faith in his aid and under his direction, to make such an examination of the person arrested as is reasonably necessary in order to ascertain the facts which may afford such evidence, and to use such force as is reasonably necessary for that purpose. Reasonable ground for believing that an examination of the accused will afford evidence to the commission of an offence is the bonafide belief of the police officer. The registered medical practitioner is not concerned with it.

Under section 53[2] Cr.P.C.5, whenever the person of a female is to be examined under this section, the examination shall be made only by, or under the supervision of, a female registered practitioner. In this section examination shall include the examination of blood, blood stains, semen, swabs in case of sexual offences, sputum and sweat, hair samples and finger nail clippings by use of modern and scientific techniques including D.N.A. profiling and such other tests which the registered medical practitioner thinks necessary in particular case.

An accused released on bail is also a person arrested for the purpose of section 53 Cr.P.C.

Examination of person accused of rape by medical practitioner 5 : Under section $53 \mathrm{~A}$, when a person is arrested on a charge of committing an offence of rape or attempt to commit rape and there are reasonable grounds for believing that an examination of this person will afford evidence as to the commission of such offence, it shall be lawful for a registered medical practitioner employed in a hospital run by government or by a local authority and in the absence of such a practitioner within the radius of $16 \mathrm{Km}$. from the place where the offence has been committed by any other registered medical practitioner, acting at the request of a police officer not below the rank of a sub-inspector, and for any person acting in good faith in his aid and under his direction, to make such an examination of the arrested person and to use such force as is reasonably necessary for that purpose. 
No consent is required where the arrested person himself makes a request to the concerned court for his medico legal examination under sec 54 Cr. P.C. and the court directs the doctor to do so.

Consent and Age: Sec 87 I.P.C. - A person under the age of 18 years cannot give valid consent, whether expressed or implied, to suffer any harm which may result from an act not intended or not known to cause death or grievous hurt. e.g. consent for a wrestling competition

Sec 89 I.P.C. - a child under 12 years of age cannot give valid consent to suffer any harm which can occur from an act done in good faith and for its benefit, e.g. consent for an operation. Only a guardian can give such a consent

Under section 375 I.P.C. - sexual intercourse by a man with a girl under 15 years of age, even if she be his wife, or any other girl under 16 years of age, even with her consent, constitutes the offence of rape.

As per The Transplantation of Human Organs Act,1994 ,Donor means any person not less than eighteen years of age, who voluntarily authorizes the removal of any of his human organs for therapeutic purposes. ${ }^{4}$

The minimum age for donating blood as mentioned is eighteen years for blood donor. ${ }^{4}$

Other Important Points Regarding Consent: For compulsory vaccination, consent is provided by the law.

If any person has donated his eyes to be used for therapeutic purpose after his death, the eyes can be removed only with the consent of guardian or legal heirs.

For organ transplantation, the organs of the dead person should not be removed without the consent of the guardian or legal heirs.

Pathological autopsy should not be done without the consent of guardian or legal heirs. Specific authorization should be obtained for retention of organs and parts of body.

In medico legal autopsies [statutory authorization], consent is not required and the doctor can remove from the cadaver anything that is essential for purpose of examination.

Consent is not a defense in cases of professional negligence.

The nature of illness of a patient should not be disclosed to any third party without the consent of the patient.

Consent of spouse is not must for M.T.P.

For contraceptive sterilization, consent of both husband and wife should be obtained.

SUMMARY AND CONCLUSION: Consent is must for any type of treatment or the medical procedure. Preferably it should be taken in written and it should always be an informed consent. Blanket consent has no legal value, so consent should be taken for the specific treatment or the procedure. Consent is must for medico legal examination with certain exceptions as already discussed .Consent provides a medical practitioner legal protection in case of an action for negligence although it is not a defense for professional negligence.

\section{REFERENCES:}

1. Narayan Reddy KS : The essentials of Forensic Medicine and Toxicology, 26 ${ }^{\text {thed.,2007; }}$ Medical Book Company, Hyderabad : 41-44 
2. Bansal YS,Singh D :Medico legal aspects of informed consent; Indian Journal of Forensic Medicine and Toxicology,2007, Vol.1[1]:19-23

3. Kohli A:Medical consent in India-Ethical and legal issues;Anil Aggarwal's Internet Journal of Forensic Medicine and Toxicology,2007,vol.1[2],July-December,2007

4. Yadav M : Age of consent in medical profession;Journal of Indian Academy of Forensic Medicine,2007,Vol.29[2]:80-85

5. Universal's The code of criminal procedures, 1973 : Universal law publishing co. pvt. Ltd., Delhi : 34-35

6. Nandy A : Principles of Forensic Medicine,2nd ed.,2004; New Central Book Agency,2004 : 39-41

7. Parikh CK : Textbook of Medical Jurisprudence, Forensic Medicine and Toxicology, $6^{\text {th }}$ ed.,2007;CBS Publishers and Distributors, Delhi : 1.36-1.39,2.12

8. Dogra TD, Rudra A : Lyon's Medical Jurisprudence and Toxicology,11th ed.,2007;Delhi Law House, Delhi : 188-193 